Marketing in Asia Group

\title{
Airline Passengers' Perceived Sacrifice and Green Practices Adoption Behaviours
}

\author{
Lim Jin Wong \\ Department of Electrical and Electronic Engineering, Kolej Laila Taib, Sarawak, \\ Malaysia \\ Joseph Kee Ming Sia \\ Department of Marketing, Faculty of Business, Curtin University Malaysia \\ Tonny Heng Yew Ling \\ School of Engineering and Technology, University College of Technology Sarawak, \\ Sarawak, Malaysia
}

\begin{abstract}
The purpose of this study is to examine factors that influence airline passenger's behaviour towards green practices adoption by exploring perceived sacrifice as an antecedent to behavioural intentions to adopt green practices and green practices adoption behaviour. This study adopted the theory of planned behaviour (TPB) as the fundamental framework. The key factors of airline passenger's green practices adoption behaviour are attitude, subjective norm, perceived behavioural control, behavioural intention and perceived sacrifice. Four hundred copies of questionnaires were distributed to airline passengers to investigate their green practices adoption behaviours. The data collected were analysed using structural equation modelling. The results indicated that all theory of planned behaviour components directly or indirectly influence airline passenger's green practices adoption behaviour. Besides, perceived sacrifice negatively influences airline passenger's behavioural intention to adopt green practices and green practices adoption behaviour. The results of the study allow airlines to formulate their marketing strategies to both enhancing environmental protection efforts and attracting environmentally responsible passengers. To the best of researchers' knowledge, this is one of the first studies that examines perceived sacrifice as an antecedent to behavioural intention and behaviour amongst airline passengers in a developing country, hence contributing to existing literature.
\end{abstract}

Keywords: Airline Passenger, Behavioural Intention, Green Practices Adoption, Perceived Sacrifice, Theory of Planned Behaviour 


\section{Introduction}

Over the years, environmental issues such as global warming and pollution have become a major concern in the tourism industry (Cohen \& Cohen, 2012; Laroche, Bergeron \& Barbaro-Forleo, 2001; Packer, Ballantyre \& Hughes, 2014). According to Lenzen, Sun, Faturay, Ting, Geschke \& Malik (2018), tourism is accountable for around eight per cent of the world's carbon emissions, with aviation being one of the significant contributors of global greenhouse gas emissions such as carbon dioxide, carbon monoxide and nitrogen oxide. Fuel consumption, waste production, air and noise pollution are some of the most significant environmental impacts caused by air travel besides high level of carbon emissions (Becken, 2002). Subsequently, research on environmental issues caused by air travel has assumed greater significance over the last few years (Mayer, Ryley \& Gillingwater, 2012).

The concern about the environment has resulted in environmentally responsible behaviours amongst consumers generally, and airline passengers specifically. Emekci (2019) indicated that consumers in Turkey are more inclined to purchase green products or services if they are concerned about the environment. A study conducted by Niu, Liu, Chang \& Ye (2016) further discovered that airline passengers in Taiwan prefer to travel with environmentally friendly airlines that actively implementing green activities to protect the environment. This has created an opportunity for airlines and other business organizations to communicate their environmental initiatives to consumers through green marketing (Laroche et al., 2001). Subsequently, airlines are able to gain reputation as socially responsible corporations that could be attractive to consumers (Cowper-Smith \& de Grosbois, 2011; Mayer et al., 2012).

Existing studies in the airline industry focus on efforts to reduce cost (O'Connell \& Williams, 2016; Springer, 2017), drivers that influence the airline's environmental commitment (Cowper-Smith \& de Grosbois, 2011), passenger's perceptions of the green image associated with airlines (Mayer et al., 2012; Mayer et al., 2015), passenger's willingness to choose environmentally friendly airlines (Niu et al., 2016), airline's business model adaptation in emerging economies (Sharma et al., 2016), passenger dissatisfaction towards low-cost carriers (Herjanto, Byrnes, Rivas \& Kasuma, 2020) and cross-cultural analysis on Frequent Flyer Programs (Platz \& Józsa, 2018). However, the number of studies on airline passenger's attitude and behaviour towards green practices adoption is limited and has yet to be fully investigated. In order to address this research gap, this study thus attempts to investigate airline passenger's attitude and behaviour towards green practices adoption.

Furthermore, research on green practices adoption in the airline industry using TPB is limited and has not been widely conducted. For instance, TPB has been widely used in predicting recycling behaviour (Chan \& Bishop, 2013; de Leeuw, Valois, Ajzen \& Schmidt, 2015), intention to save water (Cooper, 2017; Fielding, Russell, Spinks \& Mankad, 2012), intention to buy green products or services (Hossain \& Lim, 2016; Chen \& Tung, 2014), intention to use alternative transportation (Afroz, Masud, Akhtar, Islam \& Duasa, 2015; Nordlund, Eriksson \& Garvill, 2013) and environmental behaviour at the workplace (Blok, Wesselink, Studynka \& Kemp, 2015; Liao, Zhao \& Zhang, 2018) to date. In order to address this research gap, 
conducting a study on green practices adoption in the airline industry using TPB is thus considered timely.

This study therefore adopts the TPB to address the above-mentioned gaps. The model is extended by adding perceived sacrifice, and this is one of the first studies that examines perceived sacrifice as an antecedent to behavioural intention and behaviour. Main purpose of this study is to examine the factors that are most likely to influence green practices adoption behaviours amongst airline passengers in Malaysia. Better understanding of airline passenger's attitude and behaviour towards green practices adoption could be beneficial for airlines. It allows airlines to formulate their marketing strategies to enhance environmental protection efforts and subsequently attract environmentally responsible passengers.

\section{Research Context}

Escalating oil prices, high operating costs, increasing competition within the industry, and air disasters are reasons that contribute to Malaysia Airlines (MAS) and AirAsia struggling to stay profitable in the Malaysian airline industry from 2009 to 2014. Although plummeting oil prices in recent years have eased some financial burdens on both airlines, they suffered unprecedented losses this year due to the COVID-19 pandemic. With the enforced lockdown in Malaysia, Malaysian citizens are not allowed to travel abroad, and foreigners are not allowed to enter the country. The demand for air travel has also reduced drastically during this pandemic. Recently, AirAsia had announced that the group sustained net losses of RM992.88 million in the second quarter of this year due to travel bans caused by the COVID-19 pandemic (The Star, 2020a).

Studies have shown that the adoption of green practices is an effective cost reduction strategy implemented by airlines (Coles, 2015; Johnson \& Gonzalez, 2013; O’Connell $\&$ Williams, 2016). For instance, electronic ticketing, web check-in and the use of electronic boarding passes allow airlines to reduce costs by saving paper. Many airlines such as United Airlines and Air Canada have implemented paperless ticketing to cut operational costs (O'Connell \& Williams, 2016). Subsequently, cost reduction leads to sustainability and survival in business. Therefore, airline companies in Malaysia need to seriously consider encouraging green practices adoption amongst passengers to reduce their operating costs. This study, therefore, examines factors that influence voluntary green practices adoption amongst airline passengers in Malaysia to warrant an effective and efficient implementation of green practices by airline companies.

Specifically, this study pursues the following research objectives:

1. To determine the factors influencing behavioural intention to adopt green practices.

2. To determine the factors influencing green practices adoption behaviour.

3. To propose a conceptual model that helps to explain green practices adoption behaviour. 
Therefore, accomplishment of the above-mentioned research objectives is likely to explain airline passengers' green practices adoption behaviours when green practices are implemented by airline companies in Malaysia.

\section{Conceptual Framework and Hypotheses}

\section{Theory of Planned Behaviour}

Theory of planned behaviour (Ajzen, 1991) was chosen as the fundamental framework for this study to investigate green practices adoption behaviour. Applications of TPB is consistent in predicting a range of environmentally friendly behaviours such as recycling behaviours (Chan \& Bishop, 2013; de Leeuw et al., 2015), intentions to save water (Cooper, 2017; Fielding et al., 2012), consumers' buying behaviours towards organic food (Yazdanpanah \& Forouzani, 2015), consumers' purchase intentions of green sportswear (Nam, Dong \& Lee, 2017), intentions to use alternative transportation (Afroz et al., 2015) and environmental behaviours in the workplace (Liao et al., 2018). Furthermore, TPB is one of the most extensively used theories to investigate behaviour and behaviour change in social marketing (David \& Rundle-Thiele, 2018; Truong, 2014).

Although TPB has been widely used to predict a wide range of behavioural intentions or behaviours, existing constructs in the model may not be sufficient when predicting certain behaviours such as green practices adoption behaviour (Bagozzi, 2007; Perugini \& Bagozzi, 2001). Therefore, Pavlou \& Fygenson (2006) suggested extending TPB with other constructs. Furthermore, Ajzen (1991) argued that TPB can be extended by adding new variables into original model or by altering the existing paths of the original model. TPB was therefore extended in this study by adding an independent construct of perceived sacrifice to examine green practices adoption behaviours amongst airline passengers in Malaysia.

\section{Perceived Sacrifice}

Attitude does not always affect behaviour, especially when it comes to environmentally friendly behaviours or green practices adoption behaviours (Gupta \& Ogden, 2009; Kollmuss \& Agyeman, 2002). This gap between attitude and behaviour is called the value-action gap or the attitude-behaviour gap (Kollmuss \& Agyeman, 2002). Gupta \& Ogden (2009) meanwhile, labelled the gap between consumers' attitudes towards the environment and the adoption of environmentally friendly behaviours as 'green gap'. The value-action gap occurs when an individual's attitude does not influence the individual's action or behaviour. Furthermore, other factors such as comfort and convenience can cause the value-action gap when performing environmentally friendly behaviour (Kollmuss \& Agyeman, 2002).

The 'green gap' between consumers' favourable attitudes towards environmental protection and their conflicting and inconsistent environmentally friendly behaviours has been a major concern for social marketers and policymakers (Moraes, Carrigan \& Szmigin, 2012). Perceived sacrifice was therefore added to the original model of TPB to better explain and predict airline passengers' green practices adoption behaviours. The concept of perceived sacrifice is derived from the concept of perceived value. 
Zeithaml (1988) defined perceived value as "the customer's overall assessment of the utility of a product based on what is received and what is given". For instance, perceived value of the airline services is rated based on the quality of the airline services received when compared to the cost of airline ticket purchased. Value received is rated high if the airline company offers full in-flight services such as inflight meal and in-flight entertainment at discounted airline ticket fares. Woodruff (1997) further enhanced the definition of perceived value as the gap between relevant benefits and sacrifices in a specific situation. Zauner, Koller \& Hatak (2015) on the other hand, indicated that perceived value is a trade-off between perceived benefit and perceived sacrifice. Perceived sacrifice can thus be defined as costs given up with the purpose of receiving benefits such as to acquire a product or service (Shukla, 2010; Zeithaml, 1988). Thus, perceived sacrifice in the present study is defined as the amount of non-monetary cost such as comfort, convenience, and effort an airline passenger is willing to surrender when adopting green practices.

Perceived sacrifice as a construct works as a barrier towards green practices adoption in the present study. In order to have a better understanding of the relationship between sacrifice and consumer behaviour, researchers have categorized perceived sacrifice into different types. Researchers thus suggested that perceived sacrifice consists of both monetary and nonmonetary factors. For instance, Yang \& Peterson (2004) considered monetary aspects such as cost as a perceived sacrifice. Putra (2005) considered perceived sacrifice as non-monetary factors such as time, search costs (energy and time consumed when researching for a product or service), and physical efforts (energy and time). Furthermore, according to Sanchez, Callarisa, Rodriguez \& Moliner (2006), sacrifice includes cost, time, effort, amount of risk, and convenience. On the other hand, Johnstone \& Tan (2015) considered comfort as another aspect of perceived sacrifice besides convenience and effort. While monetary costs such as price are not relevant in the context of green practices adoption by airline passengers, it can be argued that non-monetary sacrifices such as convenience and effort could have influences on green practices adoption behaviours. Perceived sacrifice as an additional construct, is postulated to directly influence behavioural intention to adopt green practices and green practices adoption behaviour in this study. This study is one of the first studies that examines how perceived sacrifice influences behavioural intention to adopt green practices and green practices adoption behaviour.

\section{Hypotheses}

\section{Attitude and Behavioural Intention}

TPB suggests that a person's behavioural intention is influenced by attitude towards the behaviour, subjective norm and perceived behavioural control (Ajzen, 1991). The first determinant of behavioural intention is attitude towards the behaviour. Attitude towards the behaviour is the degree to which an individual has a favourable or unfavourable evaluation of a specific behaviour. Previous studies revealed that attitude has a significant influence on behavioural intention. $\mathrm{Ng}$ \& Law (2015) discovered that favourable attitudes from consumers in Hong Kong towards green products has a significant positive effect on their intentions to buy those products. Furthermore, Fang, Ng, Wang \& Hsu (2017) found out that positive attitudes from visitors towards the use of reusable tableware significantly influence their behavioural intention to use reusable tableware. It is predicted that favourable attitude in adoption 
of green practices will strengthen the influence on behavioural intention to adopt green practices. Airline passengers who have favourable attitudes towards green practices adoption will have stronger intention to adopt green practices than those who have unfavourable attitudes towards green practices adoption. It is thus hypothesized that:

H1 Attitude towards green practices adoption has a positive influence on behavioural intention to adopt green practices.

\section{Subjective Norm and Behavioural Intention}

The second determinant of behavioural intention is subjective norm. Subjective norm is an individual's perception on the social pressures on the individual to perform or not to perform a particular behaviour (Ajzen, 1991). Airline passengers will most likely adopt green practices if their parents, friends, colleagues and partner think it is necessary. This is consistent with the findings of a number of previous studies to predict green practices adoption behaviour. In investigating electric car usage intention, Moons \& De Pelsmacker (2012) discovered that subjective norm positively influences consumers' usage intentions of the electric car. De Leeuw et al. (2015) on the other hand, suggested that subjective norm contributes to the prediction of high school students' intentions to perform pro-environmental behaviours such as recycling and saving on energy and water. Therefore, the following hypothesis is proposed:

H2 Subjective norm to adopt green practices has a positive influence on behavioural intention to adopt green practices.

\section{Perceived Behavioural Control and Behavioural Intention}

The third determinant of behavioural intention is perceived behavioural control. Ajzen \& Madden (1986) defined perceived behavioural control as "the individual's perception on how easy or difficult the performance of the behaviour is likely to be". In a study to predict intention of low carbon commuting through bicycle sharing in China, Cai, Long, Li, Liang, Wang \& Ding (2019) stated that perceived behavioural control has a positive influence on the intention. Furthermore, Nordlund er al. (2013) indicated that perceived behavioural control to perform pro-environmental behaviours such as recycling and limiting car use positively influences the intention to perform such behaviours. In the present study, airline passengers who have greater perceived behavioural controls to adopt green practices will have stronger intentions to adopt green practices such as web check-in and the use of electronic boarding pass. Therefore, this study proposes the following hypothesis:

H3 Perceived behavioural control to adopt green practices has a positive influence on behavioural intention to adopt green practices. 


\section{Behavioural Intention and Behaviour}

Behavioural intention is the main determinant of the behaviour. Behavioural intention or intention is a plan or likelihood that an individual will undertake a particular behaviour given a specific situation (Ajzen, 1991). The stronger the intention to perform the behaviour, the more likely the behaviour will be performed. Chan \& Bishop (2013) in a study to investigate recycling behaviour in Western Australia, suggested that higher household waste recycling intention leads to actual recycling behaviour of participants in the study. Furthermore, another study conducted by Wong, Afandi, Ramachandran, Kunasekaran \& Chan (2018) revealed that behavioural intentions have a positive influence on pro-environmental behaviours amongst primary school students in Malaysia. Therefore, the stronger the behavioural intentions of airline passengers to adopt green practices, the more likely they will adopt green practices implemented by airline companies. This study thus hypothesizes:

H4 Behavioural intention to adopt green practices has a positive influence on green practices adoption behaviour.

\section{Perceived Behavioural Control and Behaviour}

Ajzen (1991) proposed to consider perceived behavioural control as a determinant to predict behaviour in addition to behavioural intention because many behaviours are difficult to execute. Wang, Liu \& Qi (2014) in their study to investigate factors influencing sustainable consumption behaviours in China, indicated that perceived behavioural control has a significant positive influence on sustainable consumption behaviours. Furthermore, a study from Webb, Soutar, Mazzarol \& Saldaris (2013) identified perceived behavioural control to have a positive influence on household energy saving behaviour. In the present study, the greater the perceived behavioural controls of airline passengers to adopt green practices, the more likely they will adopt green practices. Therefore, the above discussion leads to the following hypothesis:

H5 Perceived behavioural control to adopt green practices has a positive influence on green practices adoption behaviour.

\section{Attitude and Green Practices Adoption Behaviour}

Besides positively influences behavioural intention, attitude has been found to directly influence behaviour. In a study to examine Chinese consumers' green purchase behaviours, Cheung \& To (2019) argued that both attitude towards environmental issues and attitude towards eco-social benefits have positive effects on green purchase behaviour. Furthermore, Amoako \& Dzogbenuku (2020) found out that a green attitude has a significant positive influence on the green purchasing behaviour of the youth in Ghana. In the present study, airline passengers who have favourable attitudes towards green practices adoption will more likely adopt green practices than those who have unfavourable attitudes towards green practices adoption. Per the above discussion, it is hypothesized that:

H6 Attitude towards green practices adoption has a positive influence on green practices adoption behaviour. 


\section{Subjective Norm and Green Practices Adoption Behaviour}

In a study examining green purchase behaviours amongst Malaysian consumers, Mohd. Noor, Jamil, Mat, Kasim, Muhammad \& Salleh (2012) indicated that subjective norm is positively related to green purchase behaviour. Ha, Cong \& Wall (2020), on the other hand, discovered that subjective norm has a positive relationship with marine-based environmental behaviour amongst scuba divers in China. Therefore, airline passengers who have favourable subjective norms towards green practices adoption will more likely adopt green practices implemented by airlines than those who have unfavourable subjective norms towards green practices adoption. Hence, the following relationship is hypothesized:

H7 Subjective norm to adopt green practices has a positive influence on green practices adoption behaviour.

\section{Perceived Sacrifice and Behavioural Intention}

Previous studies on green practices adoption behaviour indicated that behavioural intention is negatively influenced by perceived sacrifice. For instance, Ramayah, Lee \& Mohamed (2010) in their study to investigate green product purchase intention in a developing country, indicated that the amount of effort and convenience consumers are willing to sacrifice negatively influence the intentions to purchase green product. Additionally, Australian young low-income earners' need for temperature comfort was found to negatively influence their energy saving intentions (Russell-Bennett, Mulcahy \& Swinton, 2018). In the present study, airline passengers will have weaker intentions to adopt green practices if they have to sacrifice comfort and convenience and spend more effort when adopting green practices such as web check-in. Hence, the following hypothesis is proposed:

H8 Perceived sacrifice has a negative influence on behavioural intention to adopt green practices.

\section{Perceived Sacrifice and Behaviour}

Furthermore, perceived sacrifice as a construct is postulated to negatively influence green practices adoption behaviour amongst airline passenger in this study. This denotes that perceived sacrifice does have an influence on green practices adoption behaviour where this is consistent with the findings in a number of previous studies. According to Johnstone \& Tan (2015), various aspects of perceived sacrifice such as comfort, convenience and effort negatively influence consumers' green consumption behaviours. Furthermore, Miao \& Wei (2016) in their study to investigate consumers' pro-environmental behaviour in the lodging segment revealed that hotel customers are not willing to compromise personal comfort when staying at a hotel. Therefore, airline passengers will more likely not adopt green practices if they have to sacrifice comfort and convenience and spend more effort when adopting green practices such as web check-in. This leads to the following hypothesis:

H9 Perceived sacrifice has a negative influence on green practices adoption behaviour. 
With that, the research framework of this study is depicted in Figure 1.

Figure 1: Research Framework

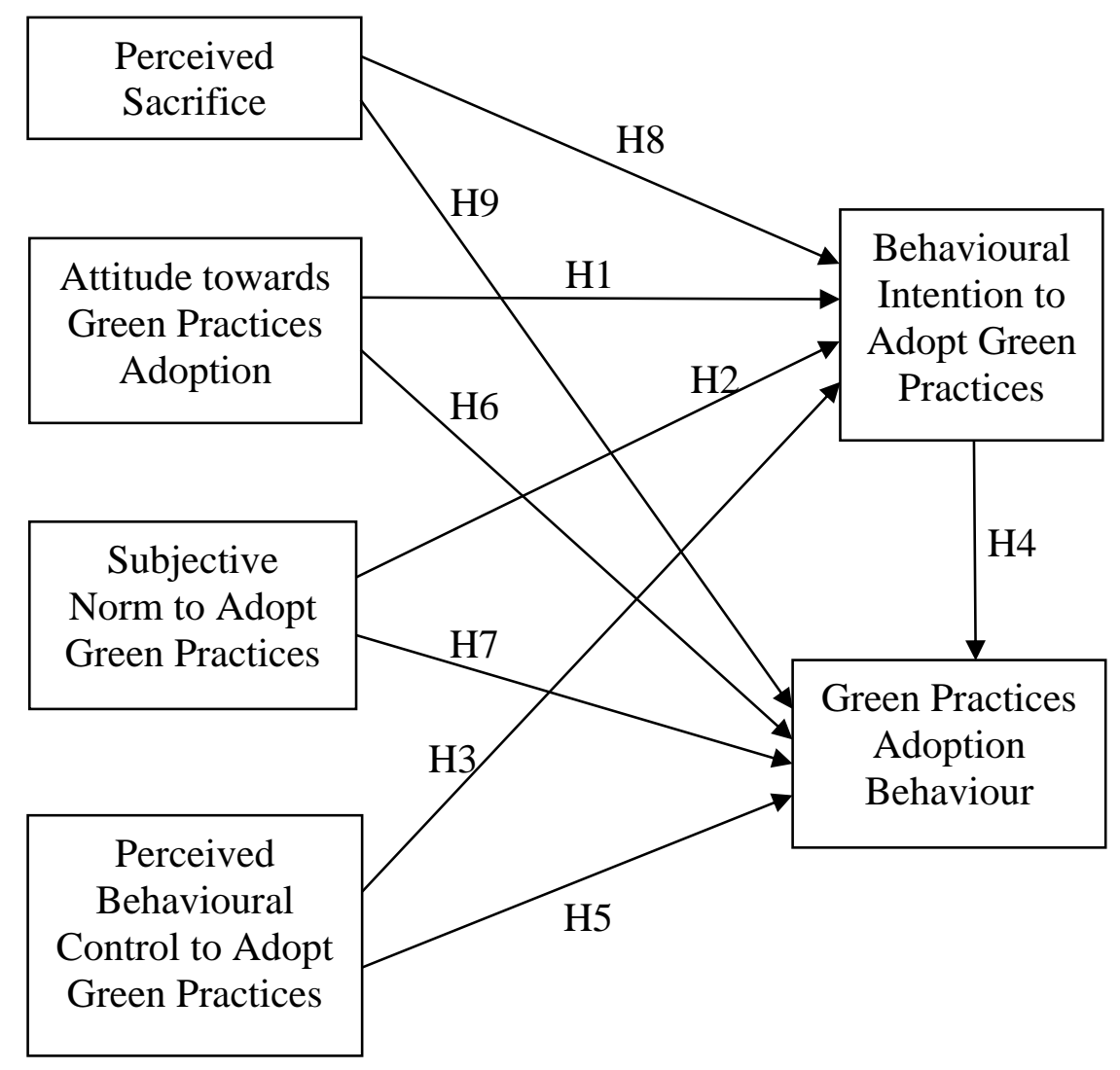

\section{Methodology}

\section{Sampling Design}

The target population in this study are all airline passengers who arrive, depart and transit at Kuala Lumpur International Airport (KLIA), including KLIA2. They were chosen as the population of this study because KLIA has the highest passenger traffic compared to other airports in Malaysia. The total passenger traffic at KLIA (including KLIA2) for the year 2017 was 59.99 million, representing 58.55 per cent of the total passenger traffic of 102.46 million at all 22 major airports in Malaysia (MAHB, 2019). Furthermore, KLIA and KLIA2 have inbound flights from nearly all major domestic and international airports in Malaysia except for smaller regional airports. Therefore, the respondents in this study include domestic and international passengers flying with all airlines at KLIA and KLIA2.

This study employed convenience sampling to select the sample. Convenience sampling has advantages such as reduced cost and higher convenience as subjects are easily available at places such as airport (Blair, Czaja \& Blair, 2014; Sekaran \& Bougie, 2013). According to Krejcie \& Morgan (1970), the sample size should be 384 only if population size is more than one million. Hair, Black, Babin \& Anderson (2014) suggested that a sample size between 200 and 400 is appropriate. Wolf, 
Harrington, Clark \& Miller (2013) on the other hand suggested that the sample size requirements for structural equation models should range from 30 to 450 . Therefore, this study used a sample size of 400 for airline passengers at KLIA because this sample size is within the range of previous studies aforementioned and structural equation modelling (SEM) requirements.

\section{Questionnaire Design}

All items in the questionnaire of this study were adapted from published literature. The questionnaire items to measure attitude, subjective norm and perceived behavioural control were adapted from Kim, Njite \& Hancer (2013). Among these three scales, attitude is a six-item scale, subjective norm is a four-item scale and perceived behavioural control is a three-item scale. Four-item scale for behavioural intention was adapted from Kim \& Han (2010). Besides, the three-item green practices adoption behaviour scale was adapted from Afroz et al. (2015). The questionnaire items to measure perceived sacrifice on the other hand, was adapted from Cronin Jr., Brady \& Hult (2000). All questionnaire items in the aforementioned previous studies were modified to better suit the context of the present study. For instance, the item "I am confident that if I want to, I can select an eco-friendly restaurant for a meal, compared to a non-eco-friendly restaurant" in Kim et al. (2013) was modified to "I am confident that if I want to, I can adopt green practices when travelling by air". Table 1 shows the questionnaire items.

Table 1: Questionnaire Items

\begin{tabular}{|c|c|c|}
\hline \multirow{3}{*}{$\begin{array}{l}\text { Construct } \\
\text { Attitude towards green } \\
\text { practices adoption } \\
\text { (ATT) }\end{array}$} & \multicolumn{2}{|l|}{ Items } \\
\hline & att1 & $\begin{array}{l}\text { For me, adopting green practices to protect } \\
\text { environment would be good. }\end{array}$ \\
\hline & revatt2 & $\begin{array}{l}\text { For me, adopting green practices to protect } \\
\text { environment would be foolish. }\end{array}$ \\
\hline & att3 & $\begin{array}{l}\text { For me, adopting green practices to protect } \\
\text { environment would be useful. }\end{array}$ \\
\hline & att4 & $\begin{array}{l}\text { For me, adopting green practices to protect } \\
\text { environment would be positive. }\end{array}$ \\
\hline & revatt5 & $\begin{array}{l}\text { For me, adopting green practices to protect } \\
\text { environment would be wrong. }\end{array}$ \\
\hline & att6 & $\begin{array}{l}\text { For me, adopting green practices to protect } \\
\text { environment would be suitable. }\end{array}$ \\
\hline $\begin{array}{l}\text { Subjective norm to } \\
\text { adopt green practices } \\
\text { (SN) }\end{array}$ & sn1 & $\begin{array}{l}\text { Most people who are important to me think I should } \\
\text { be willing to adopt green practices when traveling by } \\
\text { air. }\end{array}$ \\
\hline & $\mathrm{sn} 2$ & $\begin{array}{l}\text { People whose opinions I value would prefer that I } \\
\text { adopt green practices when traveling by air. }\end{array}$ \\
\hline & sn3 & $\begin{array}{l}\text { People who are important to me would approve of me } \\
\text { being an environmentally friendly airline passenger } \\
\text { actively adopting green practices to protect the } \\
\text { environment. }\end{array}$ \\
\hline & sn4 & $\begin{array}{l}\text { Most of the airline passengers with whom I am } \\
\text { familiar with adopt green practices on a regular basis } \\
\text { when traveling by air. }\end{array}$ \\
\hline $\begin{array}{l}\text { Perceived behavioural } \\
\text { control to adopt green } \\
\text { practices (PBC) }\end{array}$ & pbc1 & $\begin{array}{l}\text { I am confident that if I want to, I can adopt green } \\
\text { practices when traveling by air. }\end{array}$ \\
\hline
\end{tabular}




\begin{tabular}{|c|c|c|}
\hline & pbc2 & $\begin{array}{l}\text { It is up to me whether or not I become an } \\
\text { environmentally friendly airline passenger. }\end{array}$ \\
\hline & pbc3 & I have enough time to check-in my flights online. \\
\hline \multirow{4}{*}{$\begin{array}{l}\text { Behavioural intention } \\
\text { to adopt green } \\
\text { practices (INT) }\end{array}$} & int1 & I plan to check-in online in the near future. \\
\hline & int2 & I am willing to adopt green practices in future flights. \\
\hline & int3 & $\begin{array}{l}\text { I will make an effort to adopt green practices in future } \\
\text { flights. }\end{array}$ \\
\hline & int4 & $\begin{array}{l}\text { I will recommend other airline passengers to adopt } \\
\text { green practices. }\end{array}$ \\
\hline \multirow{3}{*}{$\begin{array}{l}\text { Green practices } \\
\text { adoption behaviour } \\
\text { (GPAB) }\end{array}$} & gpab1 & I often check-in my flights online. \\
\hline & gpab2 & $\begin{array}{l}\text { I often recommend other airline passengers to check- } \\
\text { in their flights online. }\end{array}$ \\
\hline & gpab3 & $\begin{array}{l}\text { When there is a choice, I always adopt green practices } \\
\text { that pose little harm to the environment when } \\
\text { traveling by air. }\end{array}$ \\
\hline \multirow[t]{3}{*}{$\begin{array}{l}\text { Perceived sacrifice } \\
\text { (SAC) }\end{array}$} & sac1 & $\begin{array}{l}\text { I believe that adopting green practices does not } \\
\text { interrupt my existing lifestyle. }\end{array}$ \\
\hline & sac2 & $\begin{array}{l}\text { I believe that check-in online does not require much } \\
\text { effort. }\end{array}$ \\
\hline & revsac 3 & I find it is inconvenient to check-in online. \\
\hline
\end{tabular}

This study used five-point Likert scales ranging from ' $1=$ strongly disagree', ' $2=$ disagree', ' $3=$ moderate', ' $4=$ agree' and ' $5=$ strongly agree' to measure the constructs. These constructs are attitude towards green practices adoption, subjective norm to adopt green practices, perceived behavioural control to adopt green practices, behavioural intention to adopt green practices, green practices adoption behaviour and perceived sacrifice.

The final questionnaire is divided into three major sections. Section A is the preliminary section containing a set of qualifying questions. Respondents were asked whether they have travelled by air and have arrived, departed and transited at KLIA or KLIA2 in the past 12 months. Furthermore, they were asked whether the airline used in their previous trip provides web check-in service and whether or not they checkedin their flights online. Only qualified respondents who had answered "yes" for all the aforementioned questions would be allowed to proceed to sections B and C. Section B of the questionnaire attains data about perceptions of airline passengers towards adoption of green practices that include attitude towards green practices adoption, subjective norm to adopt green practices, perceived behavioural control to adopt green practices, behavioural intention to adopt green practices, green practices adoption behaviour and perceived sacrifice. Finally, section $\mathrm{C}$ attains demographic profile of respondents.

\section{Data Collection}

This study employed intercept survey to collect data at KLIA in March, 2018. Intercept survey is implemented as doubts can be clarified immediately, enabling the researcher to interact directly with respondents, thus establishing strong rapport and motivating respondents to complete the questionnaires. Hence, this reduces the potential for non-response bias. Respondents were screened by asking whether they were airline passengers who had been to KLIA in the past 12 months. This is to ensure that respondents have fresh memory to complete the questionnaires accurately. 
Prior to participation, respondents were briefed the purpose of the study and their right to withdraw from participating in the survey. Anonymity of the respondents was guaranteed and no personal information was collected. Informed consent was obtained from each respondent before they agreed to participate in the survey and were given the questionnaires. Thereafter, each respondent was be given a selfadministered questionnaire to complete. One advantage of self-administered questionnaires is reduced interviewer bias (Blair et al., 2014). Furthermore, respondents were well-informed that there are no right or wrong answers, and they should answer questions as honestly as possible. According to Podsakoff, MacKenzie, Lee, and Podsakoff (2003), this should reduce respondents' evaluation apprehension, and the respondents will less likely edit their responses based on how they think the researcher wants them to respond. Thus, this subsequently reduces the common method bias. A total of 400 questionnaires had been distributed and 379 were deemed usable for data analysis. Data obtained were analysed by using Statistical Package for Social Sciences (SPSS) and SPSS Analysis of Moments Structures (SPSS AMOS).

\section{Data Analysis and Results}

\section{Descriptive Analysis}

Amongst the 379 respondents, females recorded $57.3 \%$ and males stood at $42.7 \%$. The majority of respondents were between 21 to 30 years old $(51.7 \%)$, followed by $22.2 \%$ from 31 to 40 years old group. Furthermore, $82.1 \%$ of respondents were Malaysians and the rest were non-Malaysians. Meanwhile, majority of the airline passengers at KLIA participating in the survey of this study were Malaysians. In terms of academic qualifications, majority of the respondents were diploma or bachelor degree holders $(65.2 \%)$, followed by postgraduate degree holders $(17.9 \%)$ and secondary or high school qualification (14.2\%). It is concluded majority of the respondents in this study had undergone tertiary education. In terms of occupation, $38.8 \%$ of the respondents were professionals or managers. The second largest group was students or teachers or academics at $34.8 \%$ followed by technicians or clerical works or services and sales or executives at $17.2 \%$. Besides, approximately $39.6 \%$ of the respondents have flown two to three times in the past 12 months and approximately $42.7 \%$ of them have arrived or departed at KLIA or KLIA2 in the past 12 months. Therefore, majority of the respondents were frequent airline passengers at KLIA.

\section{Common Method Variance Assessment}

Confirmatory factor analysis (CFA) was performed by modelling all items as the indicators of a single factor called common method variance (CMV) in order to assess common method bias in this study. CMV may occur if the model fits the data very well (Malhotra, Kim \& Patil, 2006). In other words, if the results show poor model fitness, CMV is assumed to be insignificant. The model indicated poor fitness, with all goodness-of-fit indices not within the respective recommended range $\left(\chi^{2}=\right.$ $3100.445, \mathrm{df}=230, \mathrm{p}$-value $=0.000, \chi^{2} / \mathrm{df}=13.480, \mathrm{GFI}=0.550, \mathrm{AGFI}=0.422$, TLI $=0.505, \mathrm{CFI}=0.550, \mathrm{RMSEA}=0.182$ ). Therefore, there was no evidence of possible CMV in this study. 


\section{Goodness-of-fit Assessment}

A pooled measurement model consisting of all constructs involved in this study was first developed using SPSS AMOS. The pooled measurement model was then analysed by using CFA. The measurement model has to first meet multiple fit indices as proposed by Hair et al. (2014). The value of normed chi-square $\left(\chi^{2} / \mathrm{df}\right)$ should be no more than 3 (Bagozzi \& Yi, 1988), and the values of RMSEA and AGFI should be no more than 0.08 (Kline, 2016) and no less than 0.80 (Chau \& $\mathrm{Hu}, 2001$ ) respectively. Furthermore, the values of GFI, CFI and TLI should exceed 0.90 (Hair et al., 2014). The goodness-of-fit indices indicated that the measurement model fitted the data adequately $\left(\chi^{2}=668.770, \mathrm{df}=215, \mathrm{p}\right.$-value $=0.000, \chi^{2} / \mathrm{df}=3.111, \mathrm{GFI}=$ $0.866, \mathrm{AGFI}=0.828, \mathrm{TLI}=0.916, \mathrm{CFI}=0.929, \mathrm{RMSEA}=0.075)$.

\section{Reliability and Validity Assessment}

CFA was performed and convergent validity was assessed using factor loadings, average variance extracted (AVE) and composite reliability, as per suggestion by Hair et al. (2014). All factor loadings should not be less than 0.70 to indicate high convergent validity (DeVellis, 2017; Hair et al., 2014). AVE and composite reliability on the other hand should not be less than 0.50 and 0.70 respectively (Hair et al., 2014). Furthermore, the Cronbach's alpha coefficient of a scale should not be less than 0.70 to achieve internal consistency reliability (DeVellis, 2017; Hair et al., 2014). Referring to Table 2, AVE, composite reliability and Cronbach's alpha values of all scales used in this study were above the recommended values aforementioned. Furthermore, the loadings for all items exceeded the recommended value of 0.70 . Therefore, convergent validity and reliability have been established for this study.

Table 2: Reliability and Validity for Each Construct

\begin{tabular}{|c|c|c|c|c|c|}
\hline Construct & Items & $\begin{array}{l}\text { Factor } \\
\text { Loadings }\end{array}$ & $\begin{array}{l}\text { Cronbach's } \\
\text { Alpha }\end{array}$ & AVE & $\begin{array}{l}\text { Composite } \\
\text { Reliability }\end{array}$ \\
\hline \multirow{6}{*}{$\begin{array}{l}\text { Attitude towards } \\
\text { green practices } \\
\text { adoption (ATT) }\end{array}$} & att1 & 0.81 & \multirow[t]{6}{*}{0.92} & \multirow[t]{6}{*}{0.67} & \multirow[t]{6}{*}{0.93} \\
\hline & revatt2 & 0.83 & & & \\
\hline & att3 & 0.85 & & & \\
\hline & att4 & 0.86 & & & \\
\hline & revatt5 & 0.82 & & & \\
\hline & att6 & 0.75 & & & \\
\hline \multirow{4}{*}{$\begin{array}{l}\text { Subjective norm to } \\
\text { adopt green } \\
\text { practices }(\mathrm{SN})\end{array}$} & sn1 & 0.86 & \multirow[t]{4}{*}{0.87} & \multirow[t]{4}{*}{0.62} & \multirow[t]{4}{*}{0.87} \\
\hline & $\operatorname{sn} 2$ & 0.86 & & & \\
\hline & sn3 & 0.72 & & & \\
\hline & sn4 & 0.70 & & & \\
\hline \multirow{3}{*}{$\begin{array}{l}\text { Perceived } \\
\text { behavioural control } \\
\text { to adopt green } \\
\text { practices (PBC) }\end{array}$} & pbc1 & 0.91 & \multirow[t]{3}{*}{0.88} & \multirow[t]{3}{*}{0.72} & \multirow[t]{3}{*}{0.89} \\
\hline & pbc2 & 0.92 & & & \\
\hline & pbc3 & 0.70 & & & \\
\hline \multirow{4}{*}{$\begin{array}{l}\text { Behavioural } \\
\text { intention to adopt } \\
\text { green practices } \\
\text { (INT) }\end{array}$} & int1 & 0.83 & \multirow[t]{4}{*}{0.93} & \multirow[t]{4}{*}{0.78} & \multirow[t]{4}{*}{0.93} \\
\hline & int 2 & 0.92 & & & \\
\hline & int3 & 0.91 & & & \\
\hline & int4 & 0.86 & & & \\
\hline \multirow{3}{*}{$\begin{array}{l}\text { Green practices } \\
\text { adoption behaviour } \\
\text { (GPAB) }\end{array}$} & gpab1 & 0.79 & \multirow[t]{3}{*}{0.82} & \multirow[t]{3}{*}{0.61} & \multirow[t]{3}{*}{0.82} \\
\hline & gpab2 & 0.82 & & & \\
\hline & gpab3 & 0.73 & & & \\
\hline
\end{tabular}




\begin{tabular}{|l|l|l|l|l|l|}
\hline \multirow{2}{*}{$\begin{array}{l}\text { Perceived sacrifice } \\
(\mathrm{SAC})\end{array}$} & sac1 & 0.81 & 0.87 & 0.70 & 0.88 \\
\cline { 2 - 3 } & sac2 & 0.91 & & & \\
\cline { 2 - 3 } & revsac3 & 0.79 & & & \\
\hline
\end{tabular}

In order to demonstrate discriminant validity, the value of square root of AVE for each construct in this study must be greater than inter-construct correlations associated with that construct (Hair et al., 2014). Referring to Table 3, all values of square root of AVE (the shaded bold elements in diagonal) were greater than interconstruct correlations in their corresponding columns. This indicates that all constructs used in this study were of adequate discriminant validity.

Table 3: Discriminant Validity of Constructs

\begin{tabular}{|c|c|c|c|c|c|c|}
\hline & 旨 & Z & U & 艺 & $\underset{0}{\stackrel{0}{0}}$ & 崫 \\
\hline ATT & 0.821 & & & & & \\
\hline SN & 0.566 & 0.789 & & & & \\
\hline PBC & 0.396 & 0.310 & $\begin{array}{l}0.850 \\
\end{array}$ & & & \\
\hline INT & 0.629 & 0.508 & 0.447 & 0.881 & & \\
\hline GPAB & 0.469 & 0.327 & 0.277 & 0.711 & 0.778 & \\
\hline SAC & -0.433 & -0.293 & -0.313 & -0.570 & -0.483 & 0.838 \\
\hline
\end{tabular}

\section{Structural Model Evaluation}

This study employed structural model evaluation to examine the relationships amongst constructs based on the research framework shown in Figure 1. The SPSS AMOS version 20 with maximum likelihood estimation (MLE) was used when evaluating structural models. The hypothesized model as shown in Figure 1 was first evaluated. Assessment of goodness-of-fit indices indicated that the hypothesized model fitted the data adequately $\left(\chi^{2}=668.770, \mathrm{df}=215, \mathrm{p}\right.$-value $=0.000, \chi^{2} / \mathrm{df}=$ 3.111, GFI $=0.866$, AGFI $=0.828$, TLI $=0.916$, CFI $=0.929, \mathrm{ECVI}=2.092$, RMSEA $=0.075)$. Table 4 lists standardized beta coefficients of all hypothesized paths in Figure 1. According to Tabachnick \& Fidell (2013), a parameter is statistically significant at the 0.05 levels when the critical value (C.R.) is greater than the absolute value of 1.96 for a regression weight. Therefore, all hypothesized paths were statistically significant and in the hypothesized direction except for ATT $\rightarrow$ $\mathrm{GPAB}, \mathrm{SN} \rightarrow \mathrm{GPAB}, \mathrm{PBC} \rightarrow \mathrm{GPAB}$, and $\mathrm{SAC} \rightarrow \mathrm{GPAB}$. Figure 2 illustrates the proposed conceptual model for green practices adoption behaviour that includes all hypothesized paths. 
Table 4: Standardized Betas of All Hypothesized Paths in the Hypothesized Model

\begin{tabular}{|l|l|l|l|l|}
\hline Hypothesized Path & Standardized Beta & C.R. & $\boldsymbol{p}$-Value & Result \\
\hline $\mathrm{ATT} \rightarrow$ INT & 0.321 & 5.633 & $* * *$ & Supported \\
\hline $\mathrm{SN} \rightarrow$ INT & 0.180 & 3.479 & $* * *$ & Supported \\
\hline $\mathrm{PBC} \rightarrow$ INT & 0.161 & 3.536 & $* * *$ & Supported \\
\hline $\mathrm{SAC} \rightarrow$ INT & -0.328 & -6.701 & $* * *$ & Supported \\
\hline $\mathrm{INT} \rightarrow \mathrm{GPAB}$ & 0.667 & 8.154 & $* * *$ & Supported \\
\hline $\mathrm{SAC} \rightarrow$ GPAB & -0.115 & -1.940 & 0.052 & Not supported \\
\hline $\mathrm{PBC} \rightarrow$ GPAB & -0.062 & -1.168 & 0.243 & Not supported \\
\hline $\mathrm{ATT} \rightarrow \mathrm{GPAB}$ & 0.056 & 0.838 & 0.402 & Not supported \\
\hline $\mathrm{SN} \rightarrow \mathrm{GPAB}$ & -0.058 & -0.954 & 0.340 & Not supported \\
\hline
\end{tabular}

Note: $* * *$ indicates $\mathrm{p}$-value $<0.001$

Figure 2: Final Model

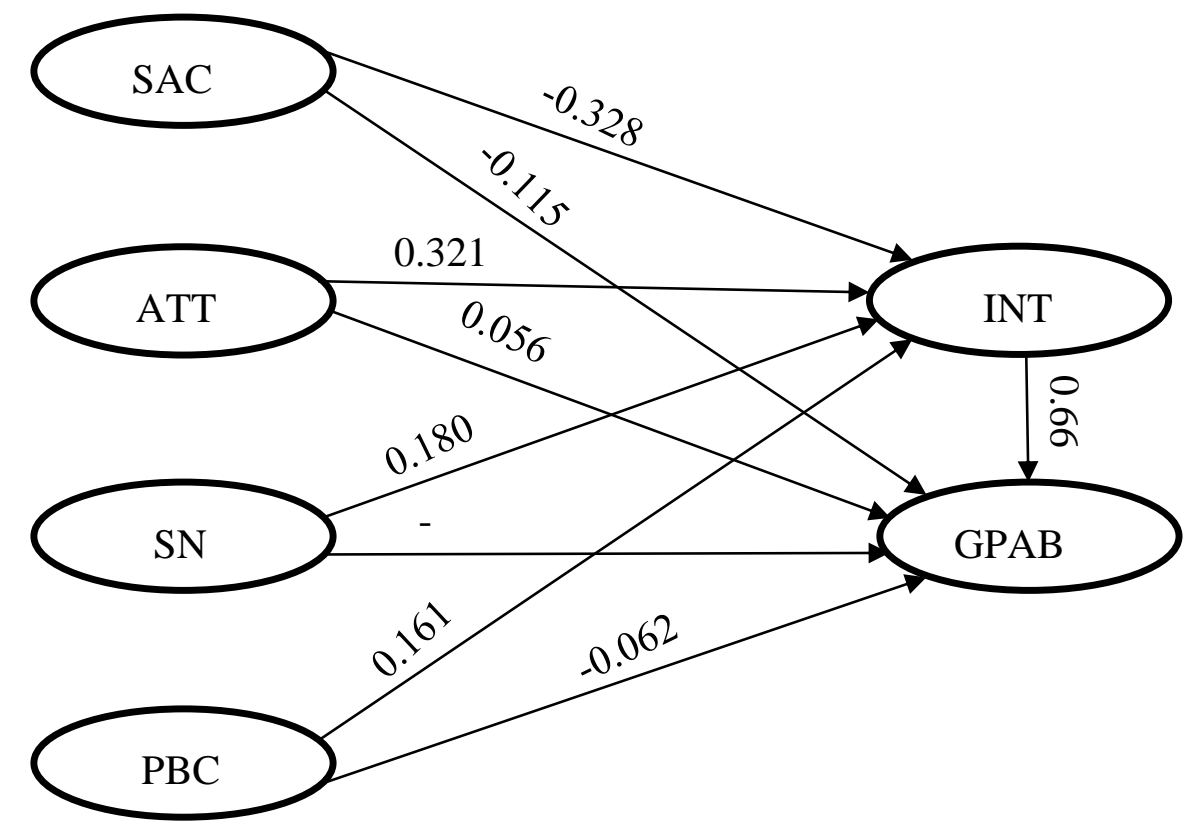

\section{Discussion}

Perceived sacrifice was found to negatively influence behavioural intentions to adopt green practices amongst airline passengers in Malaysia. Additionally, perceived sacrifice is the most significant predictor of behavioural intention to adopt green practices. The findings of the present study revealed that airline passengers are not willing to sacrifice comforts, conveniences, and exert efforts when adopting green practices. For instance, if airline passengers believe that it is inconvenient to check-in online, they will most probably not plan to check-in online in the near future. In other words, airline passengers will only make an effort to perform web check-in if they believe that adopting green practices does not interrupt their existing lifestyles and that check-in online does not require much effort. In view of this, airline companies can employ incentive marketing strategy to encourage green practices adoption behaviours amongst airline passengers. Firstly, airline companies can provide incentives such as the privilege to choose their own seat for passengers who are actively adopting green practices. Secondly, airline companies can implement a number of changes in their daily operations to minimize inconveniences caused to 
airline passengers when they are adopting green practices. This includes simplification and acceleration of the web check-in process and the use of an electronic boarding pass. These incentive marketing strategies are effective in encouraging consumers' repeated behaviours in their choices of product or service (Toker-Yildiz, Trivedi, Choi \& Chang, 2017).

However, perceived sacrifice was found to have no significant influence on green practices adoption behaviour. Numerous studies have indicated that perceived sacrifice is a strong predictor of environmentally friendly behaviours (Johnstone \& Tan, 2015; Miao \& Wei, 2016). Nevertheless, not all other studies have indicated that environmentally friendly behaviours are influenced by perceived sacrifice. For instance, Minelgaité \& Liobikiené (2019) in their study to investigate determinants of waste management behaviours in the European Union, revealed that efforts required to reduce waste only influence waste recycling behaviour, but not waste reducing and waste reusing behaviours. Therefore, the researchers can conclude that perceived sacrifice does not necessarily influence all types of environmentally friendly behaviours such as web check-in and the use of electronic boarding pass in the context of the present study. One of the reasons perceived sacrifice does not have a significant influence on green practices adoption behaviour in this study may be due to internet access has become common in everyday routine. A finding indicated that 39.2 per cent of Malaysians spend one to four hours daily using the internet as of August 2018 (Statista Research Department, 2020). Therefore, there is every chance that they will adopt green practices such as web check-in regardless of the amount of effort required.

This study discovered that attitude towards green practices adoption does not significantly influence green practices adoption behaviour. As per the model of dual attitudes (Wilson, Lindsey \& Schooler, 2000), individuals can have both explicit and implicit attitudes toward the same behaviour. An explicit attitude can be defined as conscious attitude based on an individual's beliefs about the outcomes of performing a particular behaviour, is commonly discussed and measured in social psychology as a key variable to influence behaviour such as in the Ajzen's TPB, and is usually measured using questionnaires (Muschalik, Elfeddali, Candel, Crutzen \& de Vries, 2019). Explicit attitude is easier to change and may only determine behaviour in the shorter term. Attitude towards green practices adoption in this study is considered as explicit attitude, and thus does not significantly influence green practices adoption behaviour. Contrary to the explicit attitude, the implicit attitude that exists without conscious awareness, is more difficult to change and thus more likely to determine behaviour in the longer term (Wilson et al., 2000). A study conducted by Govind, Singh, Garg \& D'Silva (2019) revealed that the implicit attitude determines behaviour but not explicit behaviour. They investigated ethical consumption, and discovered that the implicit attitude determines behaviour while explicit attitude does not have any impact on the choice of consumers.

This study revealed that subjective norm to adopt green practices does not influence green practices adoption behaviours amongst airline passengers in Malaysia. In other words, airline passengers may decide not to adopt green practices such as web checkin regardless of the opinions received from peers and persons of importance. Previous studies conducted to predict environmentally friendly behaviours suggested that subjective norm does not always influence the behaviour. For instance, Ashraf, 
Joarder \& Ratan (2019) in their study to examine the relationship between anticonsumer behavioural aspects and organic food purchase in Bangladesh, indicated that subjective norm does not significantly influence organic food purchase behaviour. In another study conducted to model the responsible attitude and behaviour of Iranian farmers with respect to the environment, Farani, Mohammadi \& Ghahremani (2019) argued that farmers' responsible environmental behaviours are not significantly influenced by the subjective norm. Therefore, the researchers can conclude that the finding of this study was consistent with a number of previous studies in which subjective norm does not have a significant influence on green practices adoption behaviour.

Notably, this study discovered that perceived behavioural control to adopt green practices does not significantly influence green practices adoption behaviour. Several previous studies also reported that perceived behavioural control does not always influence behaviour. For instance, Onel (2017) in a study to investigate the proenvironmental purchasing behaviour of consumers, suggested that perceived behavioural control does not influence behaviour. One reason contributing to inactivity amongst airline passengers is insufficient information on the advantages of adopting green practices. Furthermore, airline passengers have no obligation to adopt voluntary green practices such as web check-in and the use of the electronic boarding pass. Airline companies should therefore convey their messages to airline passengers that explain the goals of implementing green practices in the airport and during the flight. For this purpose, airline companies can employ social media marketing strategy to create and share information on social media that adopting green practices when travelling by air helps to protect the environment. Subsequently, this encourages green practices adoption behaviours amongst airline passengers who have shown concerns about the environment. A previous study also indicated that social media marketing is effective in improving consumer's behavioural engagement towards a product or service (Richard \& Guppy, 2014; Tafesse \& Wien, 2018).

Many business organizations have started to formulate strategies to promote environmentally friendly products or services in an attempt to satisfy consumers and achieve competitive advantage (Segev, Fernandes \& Hong, 2016; Tong \& Su, 2018). Airline companies can therefore employ the green marketing strategy to encourage green practices adoption behaviours amongst airline passengers. For instance, ecofriendly attributes associating with each particular green practice can be presented to the public through a variety of communication channels such as media advertisements and onboard magazines. Subsequently, airlines can gain a reputation as socially responsible corporations and capitalize on the increasing trend of green consumerism and attract more passengers (Cowper-Smith \& de Grosbois, 2011). Mayer et al. (2012) in a study conducted in England, revealed that about 50 per cent of airline passengers could differentiate between environmentally friendly and nonenvironmentally friendly airlines. Moreover, Burhanudin \& Ferguson (2018) indicated that consumers are more likely to switch from non-environmentally friendly to environmentally friendly products or services in order to save the environment. Therefore, conducting a study to get an insight into the perceptions of airline passengers towards green practices implemented by airlines is considered timely. 


\section{Theoretical Implications}

This study contributed to the literature in pro-environmental behavioural research by examining perceived sacrifice that impacts airline passengers' green practices adoption behaviours. It is one of the few studies that examine perceived sacrifice as a determinant of behavioural intention to adopt green practices and green practices adoption behaviour amongst airline passengers. By investigating the effects of a range of psychographic factors on behavioural intention to adopt green practices, the findings enrich explanation on the determinants of psychological factors in airline passenger green practices adoption behaviour. Thus, contributing to the body of knowledge in the pro-environmental behavioural realm in a developing economy.

Overall results show that behavioural intention to adopt green practices is a significant predictor towards green practices adoption behaviours amongst the airline passengers while perceived sacrifice significantly influences behavioural intention. Previous studies also indicated that barriers (perceived sacrifice) and intentions are good predictors of behaviours such as walking to and from school behaviour (David \& Rundle-Thiele, 2019). Among the two constructs, behavioural intention to adopt green practices is the most significant predictor of green practices adoption behaviour in this study. It has been acknowledged that behavioural intention is the immediate antecedent of behaviour. For instance, Onel (2017) in a study to investigate the proenvironmental purchasing behaviours of consumers, suggested that behavioural intention has a positive influence on behaviour. In the present context, if airline passengers have strong intentions to adopt green practices such as performing web check-in, they will most probably often check-in their flights online. Besides, they will often recommend other airline passengers to check-in their flights online too.

\section{Managerial Implications}

The findings from the study can be used by airlines to cut costs in operations while encouraging airline passengers to adopt green practices. One strategy to stay competitive and profitable in the airline industry is for airlines to reduce costs. Although laying off and downsizing of employees are effective cost reduction strategies, these strategies can only be used as a last resort when all other cost reduction strategies fail. Therefore, airline companies have to seriously consider encouraging green practices adoption amongst passengers as one initiative for reducing costs. Successful implementation of green marketing and incentive marketing, and social media marketing strategies discussed above will result in frequent adoption of green practices by airline passengers. Subsequently, frequent adoption of green practices amongst airline passengers helps airlines to reduce costs by using fewer resources and generating fewer wastes. For instance, electronic ticketing, web check-in, and the use of electronic boarding pass enable airlines to reduce costs through paper saving. Furthermore, baggage limits imposed on every airline passenger reduces fuel costs. A reduction in operating costs should assist airlines' survival and sustains airlines' competitiveness in the industry. 
In recent years, public individuals have gradually changed their demands, intentions, and behaviours toward green products or services in order to protect the environment (Baum, 2012; Suki, 2016). Tseng et al. (2016) reported that there is an increasing trend in green consumerism as there are growing numbers of consumers who prefer to purchase green products or services from corporations that engage in green practices in daily operations. Furthermore, Ha (2013) in a study of business ethics, indicated that consumers usually react favourably to the ethical behaviours of the business organizations. This has thus created an opportunity for airlines to encourage the adoption of green practices amongst airline passengers through green marketing. Through encouraging green practices adoption amongst airline passengers, airlines can gain a reputation as socially responsible corporations actively practicing green activities and meeting the green needs of the consumers (Lee, Abdul Wahid \& Goh, 2013; Mayer et al., 2013). Subsequently, this enables airlines to capitalize on the increasing trend of green consumerism and attract more passengers.

\section{Limitations, Future Research Direction and Conclusion}

The study has taken the first step towards the understanding of the airline passenger green adoption behaviour. However, the study did not make a comparison between gender. Future research can be conducted by using a partial least squares multi-group approach to find out if there is a difference between male and females' passengers in green adoption behaviour. A study on pro-environmental behaviour among university students in Basque elucidated that there was a significant difference between male and females' students (Vicente-Molina et al., 2018).

The generalization of the study is limited to all types of passengers in commercial flights. It is not designed to represent different clusters of passengers, for instance, senior citizens, families, disabled, and business passengers. In the same vein, the study did not examine different age groups of passengers. Thus, future research that focuses on the clusters above-mentioned and different age groups is needed, to which the current study provides a fundamental basis.

The study successfully examined the influence of perceived sacrifice, attitude, subjective norm, perceived behavioural control and behavioural intention on airline passenger green adoption behaviours. However, the study did not examine behavioural intention as a mediator. Thus, the findings have opened an additional research area in investigating other determinants that influence airline passengers in green adoption behaviour. Future research should examine other constructs, for instance, perceived threat and perceived severity as independent variables, and behavioural intention as a mediator. By the same token, it is also in response to the current global pandemic that has brought a significant impact on the airline industry. 


\section{Practical Implications for Asian Business}

The findings of the study provide practical significance to the airline industry in Southeast Asian countries. A healthy airline industry boosts tourism. This is because tourism depends on air transport to bring visitors. In year 2019, travel and tourism contributed USD380 billion to the total gross domestic product (GDP) of all Southeast Asia countries, which represented 12.1 per cent of total GDP in the region (World Travel \& Tourism Council, 2020a). Furthermore, tourism is an important industry for Malaysia as the industry has contributed significantly to the country's GDP and has resulted in the creation of jobs. According to World Travel and Tourism Council (2020b), tourism contributed RM173.3 billion to the Malaysian GDP, and this amount represented 10.3 per cent of total GDP of the country in year 2019. It is indicated that GDP directly contributed by travel and tourism sector has increased by 6.6 per cent in year 2019. Subsequently, the travel and tourism sector directly supported 2.22 million jobs in year 2019, and this represents 14.7 per cent of total employment in Malaysia (World Travel \& Tourism, 2020b). Furthermore, spending by international tourists within Malaysia was RM93.1 billion in year 2019. This amount represented 9.4 per cent of total exports of Malaysia in year 2019 (World Travel \& Tourism Council, 2020b).

However, in recent months, airlines in the region reported more than 50 per cent drop of passengers in demand in year 2020 compared to year 2019 due to COVID-19 (The Star, 2020b). Singapore Airlines reported a first-quarter net loss of more than US\$800 (RM3.4 billion) million in July 2020 (New Straits Times, 2020). Correspondingly, Thai Airways reported a net loss of Bt28 billion (RM3.68 billion) in the first half of 2020 (Chua, 2020).

In Malaysia, two major airlines namely MAS and AirAsia have suffered either net losses or reduced profits for the past few years. For instance, MAS registered a net loss of RM430.74 million for the financial year 2012 (Malaysia Airlines, 2013). In the year 2013, the airline's net losses increased to RM1.17 billion (Malaysia Airlines, 2014). Furthermore, MAS had its net losses increased by another 59 per cent in the first quarter of the year 2014 when compared to the same period a year ago, following the disappearance of flight MH370 on March 8, 2014 (The Star, 2014). Further net losses were reported by MAS at RM1.12 billion in 2015, RM438 million in 2016, RM812 million in 2017, and RM791 million in 2018 (The Edge, 2019). AirAsia meanwhile, had its net profit dropped by 54.14 per cent to RM362.12 million for the financial year 2013 (AirAsia, 2014). In year 2014, AirAsia's net profit further dropped by 77.12 per cent to RM82.84 million when compared to the year 2013 (AirAsia, 2015). The airlines reported a net loss of RM286 million in 2019 (Cirium, 2020) and RM993 million in the second quarter of 2020 (The Edge, 2020).

Given the above, the airlines in Southeast Asia countries can use the insights of the study to re-strategise their business survival in the COVID-19 pandemic. Through the findings of the study, airlines can align their marketing strategies with passenger behavioural intention to adopt green practices and green practices adoption behaviour, and thus reduction in operating costs and improve the cash flow. Since the study revealed that behavioural intention to adopt green practices was the most significant predictor of green practices adoption behaviour, airline companies in Southeast Asia could employ motivational tools to promote green practices adoption behaviour. The 
airline companies could provide incentives for passengers who are actively adopting green practices. For instance, passengers who check-in their flights online are given the priority to choose their seats, additional points for the customer loyalty program, and a complimentary drink inside the flights. Consequently, minimum staff will be deployed at the check-in counter to serve passengers that translated into a reduction in operating costs.

\section{References}

Afroz, R., Masud, M. M., Akhtar, R., Islam, M. A., \& Duasa, J., (2015), “Consumer purchase intention towards environmentally friendly vehicles: an empirical investigation in Kuala Lumpur, Malaysia”, Environmental Science and Pollution Research, vol. 22, no. 20, pp. 16153-16163.

AirAsia, (2014), "Annual report 2013", Retrieved from: http://www.airasia.com/docs/co mmon-docs/investor-relations/annual-report-2013.pdf

AirAsia, (2015), "Annual report 2014 (financials)", Retrieved from: http://www.airasia.com /docs/common-docs/investor-relations/annual-report-financials-2014.pdf

Ajzen, I., (1991), "The theory of planned behaviour", Organizational Behaviour \& Human Decision Processes, vol. 50, no. 2, pp. 179-211.

Ajzen, I., \& Madden, T. J., (1986), "Prediction of goal-directed behaviour: Attitudes, intentions and perceived behavioural control", Journal of Experimental Social Psychology, vol. 22, no. 5, pp. 453-474.

Amoako, G. K., Dzogbenuku, R. K., \& Abubakari, A., (2020), "Do green knowledge and attitude influence the youth's green purchasing? Theory of planned behaviour", International Journal of Productivity and Performance Management, vol. ahead of print, no. ahead of print.

Ashraf, M. A., Joarder, M. H. R., \& Ratan, S. R. A., (2019), "Consumers' anti-consumption behavior toward organic food purchase: An analysis using SEM", British Food Journal, vol. 68, pp. 269-275.

Bagozzi, R. P., (2007), "The legacy of the technology acceptance model and a proposal for a paradigm shift", Journal of the Association for Information Systems, vol. 8, no. 4, pp. 244-254.

Bagozzi, R. P., \& Yi, Y., (1988), "On the evaluation of structural equation models", Journal of the Academy of Marketing Science, vol. 16, no. 1, pp. 74-94.

Baum, L. M., (2012), "It's not easy being green... or is it? A content analysis of environmental claims in magazine advertisements from the United States and United Kingdom", Environmental Communication, vol.6, no. 4, pp. 423-440.

Becken, S., (2002), "Analysing international tourist flows to estimate energy used associated with air travel", Journal of Sustainable Tourism, vol. 10, no. 2, pp. 114-131.

Blair, J., Czaja, R. F., \& Blair, E. A., (2014), Designing surveys: a guide to decisions and procedures, Sage Publication, Thousand Oaks.

Blok, V., Wesselink, R., Studynka, O., \& Kemp, R., (2015), "Encouraging sustainability in the workplace: a survey on the pro-environmental behaviour of university employees", Journal of Cleaner Production, vol. 106, pp. 55-67.

Burhanudin, B., \& Ferguson, D., (2018), "Environmental issues: Managing product switching intentions among Indonesian consumers", Journal of Asia Business Studies, vol. 12, no. 1, pp. 99-116.

Cai, S. J., Long, X. L., Li, L., Liang, H., Wang, Q. L., \& Ding, X. P., (2019), "Determinants of intention and behaviour of low carbon commuting through bicycle-sharing in China", Journal of Cleaner Production, vol. 212, pp. 602-609.

Chan, L., \& Bishop, B., (2013), "A moral basis for recycling: Extending the theory of planned behaviour", Journal of Environmental Psychology, vol. 36, pp. 96-102. 
Chau, P. Y. K., \& Hu, P. J. H., (2001), "Information technology acceptance by individual professionals: A model comparison approach", Decision Sciences, vol. 32, no. 4, pp. 699-719.

Chen, M. F., \& Tung, P. J., (2014), "Developing an extended theory of planned behaviour model to predict consumers' intention to visit green hotels", International Journal of Hospitality Management, vol. 36, pp. 221-230.

Cheung, M. F. Y., \& To, W. M., (2019), "An extended model of value-attitude-behaviour to explain Chinese consumers' green purchase behaviour", Journal of Retailing and Consumer Services, vol. 50, pp. 145-153.

Chua, A., (2020), "Troubled Thai sees operating loss more than double", Retrieved from: https://www.flightglobal.com/strategy/troubled-thai-sees-operating-loss-more-thandouble/139765.article

Cirium, (2020), "AirAsia slips to full-year loss", Retrieved from https://www.flightglobal.com/strategy/airasia-slips-to-full-yearloss/136968.article\#: :t ext=AirAsia\%20Group\%20has\%20reported\%20a,net\%20profit\%20the\%20previous $\% 2$ Oyear

Cohen, E., \& Cohen, S. A., (2012), "Current sociological theories and issues in tourism", Annals of Tourism Research, vol. 39, no. 4, pp. 2177-2202.

Coles, S., (2015), "Low cost airlines: How they cut costs", Retrieved from https://www.aol.co.uk/travel/2015/02/24/low-cost-airlines-how-they-cut-costs/

Cooper, B., (2017), "What drives compliance? An application of the theory of planned behaviour to urban water restrictions using structural equation modelling", Applied Economics, vol. 49, no. 14, pp. 1426-1439.

Cowper-Smith, A., \& de Grosbois, D., (2011), "The adoption of corporate social responsibility practices in the airline industry", Journal of Sustainable Tourism, vol. 19, no. 1 , pp. 59-77.

Cronin Jr., J. J., Brady, M. K., \& Hult, G. T. M., (2000), “Assessing the effects of quality, value and customer satisfaction on consumer behavioural intentions in service environments", Journal of Retailing, vol. 76, no. 2, pp. 193-218.

David, P., \& Rundle-Thiele, S., (2018), "Social marketing theory measurement precision: a theory of planned behaviour illustration", Journal of Social Marketing, vol. 8, no. 2, pp. 182-201.

David, P., \& Rundle-Thiele, S., (2019), "Rethinking behaviour change: A dynamic approach in social marketing", Journal of Social Marketing, vol. 9, no. 2, pp. 252-268.

De Leeuw, A., Valois, P., Ajzen, I., \& Schmidt, P., (2015), "Using the theory of planned behaviour to identify key beliefs underlying pro-environmental behaviour in highschool students: implications for educational interventions", Journal of Environmental Psychology, vol. 42, pp. 128-138.

DeVellis, R. F., (2017), Scale development: theory and applications, Sage Publication, Thousand Oaks.

Emekci, S., (2019), "Green consumption behaviours of consumers within the scope of TPB", Journal of Consumer Marketing, vol. 36, no. 3, pp. 410-417.

Fang, W. T., Ng, E., Wang, C. M., \& Hsu, M. L., (2017), "Normative beliefs, attitudes and social norms: People reduce waste as an index of social relationships when spending leisure time", Sustainability, vol. 9, no. 10, pp. 1696.

Farani, A. Y., Mohammadi, Y., \& Ghahremani, F., (2019), "Modelling Farmers' responsible environmental attitude and behaviour: A case from Iran", Environmental Science and Pollution Research, vol. 26, pp. 28146-28161.

Fielding, K. S., Russell, S., Spinks, A., \& Mankad, A., (2012), "Determinants of household water conservation: The role of demographic, infrastructure, behaviour, and psychosocial variables", Water Resources Research, vol. 48, no. 10, pp. 1-12.

Govind, R., Singh, J. J., Garg, N., \& D'Silva, S., (2019), "Not walking the walk: how dual attitudes influence behavioural outcomes in ethical consumption", Journal of Business Ethics, vol. 155, no. 4, pp. 1195-1214. 
Gupta, S., \& Ogden, D. T., (2009), "To buy or not to buy? A social dilemma perspective on green buying", Journal of Consumer Marketing, vol. 26, no. 6, pp. 376-391.

Ha, J., (2013), "Factors influencing Korean consumers' ethical decision making", Advances in Management, vol. 6, no. 7, pp. 52-56.

Ha, N. T., Cong, L., \& Wall, G., (2020), “China's scuba divers' marine-based environmental behaviours", Journal of Sustainable Tourism, vol. ahead of print, no. ahead of print.

Hair Jr., J. F., Black, W. C., Babin, B. J., \& Anderson R. E., (2014), Multivariate data analysis, Pearson Education, Harlow.

Herjanto, H., Byrnes, M., Rivas, P., \& Kasuma, J., (2020), "How high can you fly? LCC passenger dissatisfaction", Asian Journal of Business Research, vol. 10, no. 2, pp. 7290.

Hossain, M. T., \& Lim, P. X., (2016), "Consumers' buying behaviour towards organic foods: Evidence from the emerging market”, Malaysian Management Review, vol. 51, no. 2, pp. 7-25.

Johnson, M. E., \& Gonzalez, A., (2013), "Estimating cost savings for aviation fuel and CO2 emission reduction strategies", Collegiate Aviation Review, vol. 31 no. 2, pp. 79-102.

Johnstone, M., \& Tan, L. P., (2015), "Exploring the gap between consumers' green rhetoric and purchasing behaviour", Journal of Business Ethics, vol. 132, no. 2, pp. 311-328.

Kim, Y., \& Han, H., (2010), "Intention to pay conventional-hotel prices at a green hotel - A modification of the theory of planned behaviour", Journal of Sustainable Tourism, vol. 18, no. 8, pp. 997-1014.

Kim, Y. J., Njite, D., \& Hancer, M., (2013), “Anticipated emotion in consumers' intentions to select eco-friendly restaurants: Augmenting the theory of planned behaviour", International Journal of Hospitality Management, vol. 34, pp. 255-262.

Kline, R. B., (2016), Principles and practice of structural equation modelling, The Guilford Press, New York.

Kollmuss, A., \& Agyeman, J., (2002), "Mind the gap: Why do people act environmentally and what are the barriers to pro-environmental behaviour?", Environmental Education Research, vol. 8, no. 3, pp. 239-260.

Krejcie, R. V., \& Morgan, D. W., (1970), "Determining sample size for research activities", Educational and Psychological Measurement, vol. 30, no. 3, pp. 607-610.

Laroche, M., Bergeron, J., \& Barbaro-Forleo, G., (2001), "Targeting consumers who are willing to pay more for environmentally friendly products", Journal of Consumer Marketing, vol. 18, no. 6, pp. 503-520.

Lee, C. H., Abdul Wahid, N., \& Goh, Y. N., (2013), "Perceived drivers of green practices adoption: A conceptual framework", Journal of Applied Business Research, vol. 29, no. 2, pp. 351-360.

Lenzen, M., Sun, Y. Y., Faturay, F., Ting, Y. P., Geschke, A., \& Malik, A., (2018), "The carbon footprint of global tourism", Nature Climate Change, vol. 8, no. 6, pp. 522-528.

Liao, C. H., Zhao, D. T., \& Zhang, S., (2018), "Psychological and conditional factors influencing staff's takeaway waste separation intention: An application of the extended theory of planned behaviour", Sustainable Cities and Society, vol. 41, pp. 186-194.

Malaysia Airlines, (2013), “Annual report 2012”, Retrieved from: http://ir.chartnexus.com/mas/doc/ar/ar2012.pdf

Malaysia Airlines, (2014), “Annual report 2013”, Retrieved from: http://ir.chartnexus.com/mas/doc/ar/ar2013.pdf

Malaysia Airports Holdings Berhad, (2019), "Airport statistics 2018", Retrieved from: http://annualreport2018.malaysiaairports.com.my/downloads/airportstatistics2018.pdf

Malhotra, N. K., Kim, S. S., \& Patil, A., (2006), "Common method variance in IS research: A comparison of alternative approaches and a reanalysis of past research", Management Science, vol. 52, no. 12, pp. 1865-1883.

Mayer, R., Ryley, T., \& Gillingwater, D., (2012), "Passenger perceptions of the green image associated with airlines", Journal of Transport Geography, vol. 22, pp. 179-186. 
Mayer, R., Ryley, T., \& Gillingwater, D., (2015), "Eco-positioning of airlines: Perception versus actual performance, Journal of Air Transport Management, vol. 44-45, pp. 8289.

Miao, L., \& Wei, W., (2016), “Consumers' pro-environmental behaviour and its determinants in the lodging segment", Journal of Hospitality \& Tourism Research, vol. 40, no. 3, pp. 319-338.

Minelgaité, A., \& Liobikiené, G., (2019), "Waste problem in European Union and its influence on waste management behaviours", Science of the Total Environment, vol. 667, pp. 86-93.

Mohd. Noor, N. A., Jamil, C. Z. M., Mat, N., Kasim, A., Muhammad, A., \& Salleh, H., (2012), "The relationships between environmental knowledge, environmental attitude and subjective norm on Malaysian consumers green purchase behaviour", Malaysian Journal of Consumer and Family Economics, vol. 15, no. 1, pp. 1-20.

Moons, I., \& De Pelsmacker, P., (2012), "Emotions as determinants of electric car usage intention", Journal of Marketing Management, vol. 28, no. 3/4, pp. 195-237.

Moraes, C., Carrigan, M., \& Szmigin, I., (2012), "The coherence of inconsistencies: attitudebehaviour gaps and new consumption communities", Journal of Marketing Management, vol. 28, no. 1/2, pp. 103-128.

Muschalik, C., Elfeddali, I., Candel, M., Crutzen, R., \& de Vries, H., (2019), "Does the discrepancy between implicit and explicit attitudes moderate the relationships between explicit attitude and (intention to) being physically active?", BMC Psychology, vol. 7, no. 1 , pp. 1-14.

Nam, C., Dong, H., \& Lee, Y., (2017), "Factors influencing consumers' purchase intention of green sportswear", Fashion and Textiles, vol. 4, no. 1, pp. 19-36.

New Straits Times, (2020), "Virus-hit Singapore Airlines suffers RM3.4 billion Q1 loss", Retrieved from: https://www.nst.com.my/business/2020/07/612704/virus-hit-singaporeairlines-suffers-rm34-billion-q1-loss

Ng, M. C. H., \& Law, M., (2015), "Encouraging green purchase behaviours of Hong Kong consumers", Asian Journal of Business Research, vol. 5, no. 2, pp. 1-17.

Niu, S. Y., Liu, C. L., Chang, C. C., \& Ye, K. D., (2016), "What are passenger perspectives regarding airlines' environmental protection? An empirical investigation in Taiwan", Journal of Air Transport Management, vol. 55, no. C, pp. 84-91.

Nordlund, A., Eriksson, L., \& Garvill, J., (2013), "Barriers and facilitators for proenvironmental behaviour", in Söderholm, P. (Ed.), Environmental Policy and Household Behaviour: Sustainability and Everyday Life, Earthscan, Gateshead, UK, pp. 99-128.

O'Connell, J. F., \& Williams, G., (2016), Air transport in the 21st century: key strategic developments, Routledge, New York.

Onel, N., (2017), "Pro-environmental purchasing behaviour of consumers: The role of norms", Social Marketing Quarterly, vol. 23, no. 2, pp. 103-121.

Packer, J., Ballantyne, R., \& Hughes, K., (2014), “Chinese and Australian tourists' attitudes to nature, animals and environmental issues: Implications for the design of naturebased tourism experiences", Tourism Management, vol. 44, pp. 101-107.

Pavlou, P. A., \& Fygenson, M., (2006), "Understanding and predicting electronic commerce adoption: An extension of the theory of planned behaviour", MIS Quarterly, vol. 30, no. 1, pp. 115-143.

Perugini, M., \& Bagozzi, R. P., (2001), "The role of desires and anticipated emotions in goaldirected behaviours: Broadening and deepening the theory of planned behaviour", British Journal of Social Psychology, vol. 40, no. 1, pp. 79-98.

Platz, P., \& Józsa, L., (2018), "Cross-cultural analysis of the Frequent Flyer Programs (FFPs): The most controversial results", Asian Journal of Business Research, vol. 8, no. 2, pp. 72-93.

Putra, M., (2005), "Linking perceived value and loyalty in location-based mobile services", Managing Service Quality, vol. 15, no. 6, pp. 509-538. 
Ramayah, T., Lee, J. W. C., \& Mohamed, O., (2010), "Green product purchase intention: Some insights from a developing country", Resources, Conservation and Recycling, vol. 54, no. 12, pp. 1419-1427.

Richard, J. E., \& Guppy, S., (2014), "Facebook: Investigating the influence on consumer purchase intention", Asian Journal of Business Research, vol. 4, no. 2, pp. 1-15.

Russell-Bennett, R., Mulcahy, R., \& Swinton, T., (2018), "Money or mind? What matters most in influencing low-income earners to be energy efficient?", Journal of Social Marketing, vol. 8, no. 1, pp. 2-23.

Sanchez, J., Callarisa, L., Rodriguez, R. M., \& Moliner, M. A., (2006), "Perceived value of the purchase of a tourism product", Tourism Management, vol. 27, no. 4, pp. 394-409.

Segev, S., Fernandes, J., \& Hong, C., (2016), "Is your product really green? A content analysis to reassess green advertising", Journal of Advertising, vol. 45, no. 1, pp. 85-93.

Sekaran, U., \& Bougie, R., (2013), Research methods for business, John Wiley \& Sons Ltd, West Sussex.

Sharma, S., Dixit, M. R., \& Karna, A., (2016), "Design leaps: Business model adaptation in emerging economies", Journal of Asia Business Studies, vol. 10, no. 2, pp. 105-124.

Shukla, P., (2010), "Effects of perceived sacrifice, quality, value, and satisfaction on behavioural intentions in the service environment", Services Marketing Quarterly, vol. 31, no. 4, pp. 466-484.

Springer, S., (2017), "Watch your waste: The problem with airline food and packaging", Retrieved from: https://edition.cnn.com/travel/article/airlines-cabin-waste/index.html

Statista Research Department, (2020), "Average time spent online in Malaysia as of August 2018", Retrieved from: https://www.statista.com/statistics/973288/malaysia-daily-timespent-online/

Suki, N. M., (2016), "Consumer environmental concern and green product purchase in Malaysia: structural effects of consumption values", Journal of Cleaner Production, vol. 132, pp. 204-214.

Tabachnick, B. G., \& Fidell, L. S., (2013), Using multivariate statistics, Pearson Education, New Jersey.

Tafesse, W., \& Wien, A., (2018), "Using message strategy to drive consumer behavioural engagement on social media", Journal of Consumer Marketing, vol. 35, no. 3, pp. 241253.

The Edge, (2019), "Malaysia Airlines FY18 net loss narrows to RM791.7 million", Retrieved from: https://www.theedgemarkets.com/article/malaysia-airlines-fy 18 -net-loss-narrows -rm7917-million

The Edge (2020), "AirAsia's net loss widens to RM993m in 2Q as full Covid-19 impact hits", Retrieved from: https://www.theedgemarkets.com/article/airasia-group-2q-net-lossrm99289m-versus-rm1734m-net-profit-year-

earlier\#: :text=55\%20million\%20in\%20the\%20first,brunt $\% 20$ of $\% 20$ the $\% 20$ pandemic $\% 20$ outbreak

The Star, (2014), "Missing airplane mystery deepens Malaysia Airlines losses by 59\%", Retrieved from: http://www.thestar.com/business/2014/05/15/missing_airplane_myster y_deepens_malaysia_airlines_losses_by_59.html

The Star, (2020a), "AirAsia group looks past 2Q losses, says enough working capital to sustain biz ops", Retrieved from: https://www.thestar.com.my/business/businessnews/2020/08/25/airasia-group-looks-past-2q-losses-says-enough-working-capital-tosustain-biz-ops

The Star, (2020b), "Asia's airlines fear huge losses due to Covid-19 and extended lockdowns", Retrieved from: https://www.thestar.com.my/news/regional/2020/04/25/asia039s-airlin es-fear-huge-losses-due-to-covid-19-and-extended-lockdowns

Tseng, M. L., Tan, K. H., Geng, Y., \& Govindan, K., (2016), "Sustainable consumption and production in emerging markets", International Journal of Production Economics, vol. 181, no. B, pp. 257-261. 
Toker-Yildiz, K., Trivedi, M., Choi, J. H., \& Chang, S. R. (2017), "Social interactions and monetary incentives in driving consumer repeat behaviour", Journal of Marketing Research, vol. 54, no. 3, pp. 364-380.

Tong, X., \& Su, J., (2018), "Exploring young consumers' trust and purchase intention of organic cotton apparel", Journal of Consumer Marketing, vol. 35, no. 5, pp. 522-532.

Truong, V., (2014), "Social marketing a systematic review of research 1998-2012", Social Marketing Quarterly, vol. 20, no. 1, pp. 15-34.

Vicente-Molina, M. A., Fernández-Sainz, A., \& Izagirre-Olaizola, J., (2018), "Does gender make a difference in pro-environmental behaviour? The case of the Basque Country University students", Journal of Cleaner Production, vol. 176, pp. 89-98.

Wang, P., Liu, Q., \& Qi, Y., (2014), "Factors influencing sustainable consumption behaviours: A survey of the rural residents in China", Journal of Cleaner Production, vol. 63, pp. 152-165.

Webb, D., Soutar, G. N., Mazzarol, T., \& Saldaris, P., (2013), "Self-determination theory and consumer behavioural change: Evidence from a household energy-saving behaviour study", Journal of Environmental Psychology, vol. 35, pp. 59-66.

Wilson, T. D., Lindsey, S., \& Schooler, T. Y., (2000), "A model of dual attitudes", Psychological Review, vol. 107, pp. 101-126.

Wolf, E. J., Harrington, K. M., Clark, S. L., \& Miller, M. W., (2013), "Sample size requirements for structural equation models an evaluation of power, bias, and solution propriety”, Educational and Psychological Measurement, vol. 73, no. 6, pp. 913-934.

Wong, C. A., Afandi, S. H. M., Ramachandran, S., Kunasekaran, P., \& Chan, J. K. L., (2018), I "Conceptualizing environmental literacy and factors affecting pro-environmental behaviour", International Journal of Business and Society, vol. 19, no. S1, pp. 128-139.

Woodruff, R. B., (1997), "Customer value: The next source for competitive advantage", Journal of the Academy of Marketing Science, vol. 25, no. 2, pp. 139-153.

World Travel \& Tourism Council, (2020a), "Economic impact reports", Retrieved from: https://wttc.org/Research/Economic-Impact

World Travel \& Tourism Council, (2020b), "Malaysia 2020 annual research: key highlights", Retrieved from: https://wttc.org/Research/Economic-Impact/moduleId/704/itemId/155 /controller/DownloadRequest/action/QuickDownload

Yang, Z., \& Peterson, R. T., (2004), "Customer perceived value, satisfaction and loyalty: The role of switching costs", Psychology \& Marketing, vol. 21, no. 10, pp. 799-822.

Yazdanpanah, M., \& Forouzani, M., (2015), "Application of the theory of planned behaviour to predict Iranian students' intention to purchase organic food", Journal of Cleaner Production, vol. 107, pp. 342-352.

Zauner, M., Koller, M., \& Hatak, I., (2015), "Customer perceived value - Conceptualization and avenues for future research", Cogent Psychology, vol. 2, no. 1, pp. 5-21.

Zeithaml, V. A., (1988), "Consumer perceptions of price, quality and value: A means-end model and synthesis of evidence", Journal of Marketing, vol. 52, no. 3, pp. 2-22. 